\title{
Basic Concepts, Psychology and Injury Prevention in Kitesurfing
}

\author{
Alicia Garcia-Falgueras* \\ University Researcher, Psychobiology, Spain
}

Submission: April 13, 2018; Published: June 22, 2018

*Corresponding author: Alicia Garcia-Falgueras, University Researcher, Psychobiology, Spain, Tel: 0034 627082707; Email: algarfal@hotmail.com

\begin{abstract}
Kitesurfing has become a very popular sport in the recent years, which displays its performances over the water and with the wind. However, very little is known about its basic principles, possible injuries or risks or what is required in terms of psychological and physical skills to be able to enjoy this unpredictable and relatively recent sport. We explain in this text briefly those concepts and ideas and point out the psychological perspective for this sport to be practiced in healthy conditions. We also suggest some easy physical exercises to warm up before any training or practicing for kitesurfing. Specific groups of muscles are described to work on them for being ready to cope with the changing environmental conditions of this sport.
\end{abstract}

Keywords: Kite; Kitesurf; Windsurf; Sports; Nature; Wind; Dinghy sailoring

\section{Introduction}

In kitesurfing, there are different skill levels: beginner, intermediate, advanced and expert. Both aerobic and anaerobic metabolisms contribute to energy deliver in this very demanding of motivation sport (Bourgois et al., 2014) [1]. The athletes who are expert can manage the practice almost automatically, combining his/her movements and its variations according to the angles of resistance. The direction of the wind and its force over the kite, while surfing along with the waves on the surface of the water are elements of certain level of unpredictability. Those might be the reasons why this sport is being so popular in the recent years (van Bergen et al., 2016) [2]. As a results of this combination of two forces (wind and waves), a certain randomness might occur and extent during its execution or performance. The vertical lift of the kite makes possible to perform jumps up to $15 \mathrm{~m}$ high and $30 \mathrm{~m}$ long, while doing pirouettes or tricks in the air (Bourgois et al., 2014) [1].

The athlete, who is surfing over a kiteboard, can control the kite using a handlebar, which is connected to the kite. The wrist or harness of the kitesurfer is connected to 1 of the 4 lines by a kite leash. A kite leash prevents the kite from blowing away in case the athlete loses control of the handle bar. The size of the kites varies according to market (Nickel et al., 2004) [3]. The athlete has to be physically and mentally prepared to cope with those randomness of those situations. This mixed aerodynamic characteristic that are the feature of managing the wind plus waves to sail and fly, would allow the performance to result in very striking, surprising, unpredictable, beautiful and mesmerizing pirouettes. Kitesurfing might be at certain point, similar to dinghy sailoring having both more isometric activation of upper and lower body movements (Bourgois et al., 2014) [1].

Psychology

For practicing sports in contact with nature it is required the creation of a training routine with discipline to learn the muscles involved in the sport together with the most likely and possible adversities to happen in the environment. This goal requires some time and dedication to learn the specific muscle movements of balance over the table during the surfing until it is memorized and automated. Some clues for a healthy and success life in sport are: Positive ideas for a proactive thinking; the ability of abstraction thinking to concentrate and focus on sport requirements and body specific muscles; the ability to see and balance the relativity between the terms success and failure in sport. Similarly training for adaptability and flexibility of kitesurfers to different fields and environmental conditions using the same sportive tools, as randomness, chance or luck are important elements to consider.

\section{Basic Principles}

For those persons who are interested to start as beginners in practicing this sport, hereby some useful information, principles and basics clues of initiation (Table 1 and 2). 


\section{Psychology and Behavioral Science International Journal}

Table 1:

\begin{tabular}{|c|c|}
\hline Patent & $\begin{array}{l}\text { Year 1977: the Dutch Gijsbertus Adrianus Panhuise patented the non-commercial idea of kitesurfing, consisting } \\
\text { of a board attached to a kite by harness. } \\
\text { Year 1984: French brothers Dominique and Bruno Legaignoux added a mobile skeleton or rib to the kite, } \\
\text { inflatable nowadays and a foot strap that is still used. }\end{array}$ \\
\hline With Who & $\begin{array}{l}\text { Being a wind sport, it can be practiced in the company of windsurfers. However it is not that easy to share the } \\
\text { same space with surfers, bathers or fishermen. }\end{array}$ \\
\hline Where in Spain & $\begin{array}{l}\text { Atlantic zone with Cierzo wind. } \\
\text { Cantabrian area with Galerna wind. } \\
\text { Levante area with the Tramontana and Mistral winds. } \\
\text { South zone (Sanci Petri) with the Levante wind. }\end{array}$ \\
\hline When & Both summer and winter, with the appropriate equipment and preparation. \\
\hline Some Styles & $\begin{array}{l}\text { Free practice (free-ride) } \\
\text { On waves (wave riding) } \\
\text { Navigation propelled (wake style) } \\
\text { With body grip to the kite (hooked freestyle) } \\
\text { Without support to the feet (strapless freestyle) }\end{array}$ \\
\hline Novelties in Equipment & $\begin{array}{l}\text { Clickbar 2017: to boost or depower the kite by pressing a button located on the side of the bar, which at each } \\
\text { click shortens or lengthens the back lines of the kite. The Trim Unit is visually controlled all the time. } \\
\text { New materials and composition of the surfboards: technora net (para-aramid fiber), bamboo tech (low weight } \\
\text { and high resistance) and cork shock absorver (absorbs impacts and recovers form). } \\
\text { New designs of kites: greater lightness and robustness, more effective in ascension even with little wind and } \\
\text { stability without vibration. }\end{array}$ \\
\hline
\end{tabular}

Table 2:

\begin{tabular}{|c|c|}
\hline Wind & $\begin{array}{l}\text { For naïve trainers, beginners and intermediate, a wind speed of } 10 \text { knots is necessary and for the advanced and } \\
\text { expert, the wind speed can be } 6 \text { knots. }\end{array}$ \\
\hline Physical Preparation & $\begin{array}{l}\text { Abdomen muscles (core, abdominals and gluteus) for balance. } \\
\text { Leg muscles (quadriceps, femoral muscles, calves and extensor digitorum) and arms (biceps, triceps, deltoids, } \\
\text { supraspinatus). }\end{array}$ \\
\hline $\begin{array}{l}\text { Psychological } \\
\text { Preparation }\end{array}$ & $\begin{array}{l}\text { Analytical capacity and observational abilities to calibrate the meteorology and natural phenomena. } \\
\text { Ability to concentrate and focus all senses in the sport and own body, before and during its execution. } \\
\text { Ability for automatic calculation of movements and risks considering all the variables. }\end{array}$ \\
\hline \multirow{2}{*}{$\begin{array}{l}\text { Sportive Federations in } \\
\text { Spain, France, Germany. }\end{array}$} & $\begin{array}{l}\text { kitesurfing belongs to the Royal Spanish Sailing Federation (RFEV), light sailing as a non-Olympic sport. } \\
\text { In France, where they practice kitesurfing in lakes and open sea, it is included within the Federation of Free Flight. } \\
\text { In Germany, the German Kitesurf Association (GKA) is the most renamed institution that preserved kitesurfers good } \\
\text { conditions for sporting. }\end{array}$ \\
\hline & $\begin{array}{c}\text { The Global-Kitesport organization is collecting all the information from different countries federations. } \\
\text { The International Kiteboarding Association (IKA) is the only kiteboarding class inside the International Sailing } \\
\text { Federation (ISAF). }\end{array}$ \\
\hline
\end{tabular}

\section{Possible Injuries and Prevention}

Risk of injury, defined as any physical or psychological complaints resulted in incapacity to practice or compete normally (Nickel et al., 2004; Silva et al., 2015) [3,4] does exist in kitesurf. They could appear occasionally, more frequently when training than during competition and in less experienced kitesurfers by wrong absorption of impacts on falling over land or water, circumstances and technical innovations (Bourgois et al., 2014) [1]. Most of the contusions occurred because the uncontrolled kite pulled the athlete against an obstacle (stone, mole, sailing boat) (Nickel et al., 2004) [3]. Due to technical mistakes with collisions against rocks, boats etc. (Bourgois et al., 2014) [1]. Sometimes athletes have overestimated their expertise or misinterpretation of the weather or changes in the wind conditions occurs. Minor injuries have been described because of collisions with other kitesurfers (bruises, hematomas) (Baumbach et al., 2017) [5]. being the most common injury superficial wounds, sprains and tendinitis (Silva et al., 2015) [4].

But severe injuries also occur (injuring vertebral and tibial plateau fractures) and therefore, catastrophic injuries might occasionally happen, leading to permanent disability or even death (Nickel et al., 2004) [3]. The injury rates were 7.0 per 1000 hours of kitesurfing (van Bergen et al., 2016) [2]. Being mainly located in the lower trunk: sprained ankles, leg fractures, but also on upper trunk such as shoulders and arms (dislocations, contractures, etc), although head and cervical spine lesions have been also described. It is remarkable to notice in a group of Dutch kitesurfers athletes only 28\% used protective gear such as body helmets and body protectors (impact vests) [2]. The most commonly acute injured sites were foot and ankle 
(28\%), skull (14\%), chest (13\%) and knee (13\%) (Nickel et al., 2004) [3]. It has been described that the majority of injuries usually and occasionally occur at a wind speed of 11 and 18 knots at flat-water conditions (Nickel et al., 2004) [3]. A case of chronic disease has been described in a kitersurfer athlete with multiple liver lesions (Buchholtz and Rudan, 2007) [6]; and also chronic pain during kitesurfing, associated to an old injury in consequence of kitesurfing (poor landing or after a trick), has been described Silva et al. [4].

In literature exists information about minor lesions in this sport, being almost $50 \%$ mainly haematomas, bruises or cuts

Table 3: and appearing more often in rate in woman athlete than in men athlete. Sports have many psychological benefits to health and the inertial force is very powerful in this and other sports (Garcia-Falgueras, 2015; 2017) [7,8]. However, the inertial force might also become the reason of a lesion. The existence of previous warm-up/stretching or not, was associated with injury rate (Baumbach et al., 2017) [5]. We would like to present a set of useful warming exercises aimed to avoid lesions in kitesurfing, to increase a better control over inertial force and to raise athlete's confidence on his/her body and muscles for a better performance and enjoyment sport (Table 3) (Garcia-Falgueras, 2015 and 2017) [7 and 8].

\begin{tabular}{|c|}
\hline $\begin{array}{l}\text { Ankle and Knee Exercises } \\
\text { Over and unstable surface this is a balance exercise to activate the } \\
\text { ankle (soleus muscle, peroneus longus), knees, calves and legs (tibialis } \\
\text { anterior, femoral biceps and femur). }\end{array}$ \\
\hline $\begin{array}{l}\text { Ankle Stretching } \\
\text { With a thera band, this easy exercise might help to stretch ankles by } \\
\text { using the centripetal resistance and joint dorsiflexion. }\end{array}$ \\
\hline $\begin{array}{l}\text { Legs and Knees } \\
\text { Ascending and descending with a fitball or another rolling surface on } \\
\text { wall. This exercise is aimed to activate legs: quadriceps, femoral rectus, } \\
\text { femoral biceps and muscle internal coarse. Also gluteus and calves. }\end{array}$ \\
\hline $\begin{array}{l}\text { Shoulders and Back } \\
\text { For a balance exercise, with a simple stick, rotations from front to back } \\
\text { as "dislocations". This exercise is aimed to activate and tonificate the } \\
\text { deloid, trapezius, greater round and latissimus dorsi. }\end{array}$ \\
\hline $\begin{array}{l}\text { Abdominals or Core Exercises } \\
\text { These muscles are very important for toning and maximizing the } \\
\text { balance over the kiteboard while controlling the kite. Abdominal } \\
\text { muscles, rectus abdominis, external and internal oblique, serratus } \\
\text { might be on for the kitesurfing practice. }\end{array}$ \\
\hline
\end{tabular}

\section{Acknowledgement}

Text by Alicia García Falgueras, PhD (Psychology and sports instructor). Exercises supervised by Dr. Bernáldez (Medical specialist in sports Traumatology and Orthopedic surgery. Bernáldez Clinic, Seville, registered number: 41213966). We appreciate the information provided by the kitesurfer and monitor Gino Malvell (Why-not-fly_Airush Tarifa) and the specialized store «Kitesurf Chiclana» (Barrosa beach, second arena).

\section{Credits of Pictures}

Pictorial reproductions and photographs presented in this work come from files with free license in the public domain as Wikimedia Commons. 


\section{References}

1. Bourgois JG, Boone J, Callewaert M, Tipton MJ, Tallir IB (2014) Biomechanical and physiological demands of kitesurfing and epidemiology of injury among kitesurfers. Sports Med 44(1): 55-66.

2. Van Bergen CJA, Commandeur JP, Weber RIK, Haverkamp D, Breedelveld RS (2016) Windsurfing vs kitesurfing: injuries at the North Sea over a 2-year period. World J Orthop 7: 814-820.

3. Nickel C, Zernial O, Musahl V, Hansen U, Zantop T, et al. (2004) A prospective study of kitesurfing injuries. Am J Sports Med 32: 921-927.

4. Silva B, Viana R, Gama A, Pérez-Turpin JA, Bezerra P (2015) Injuries among Portuguese kitesurfers: the most affected body regions A pilot study. Motricidade 11: 127-133.

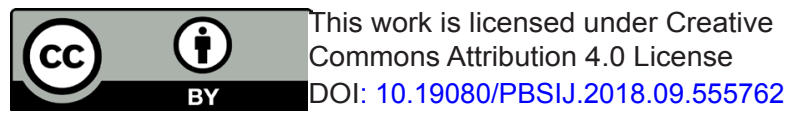

5. Baumbach SF, Stawinski T, Schmitz D, Schoeneberg C, Jäger M, et al. (2017) Influence of kitesurf equipment on injury rates. J Sports Med Phys Fitness 152-153.

6. Buchholz S, Rudan G (2007) A professional kitesurfer with multiple liver lesions. Med J Aust 187(10): 590-591.

7. Garcia-Falgueras A (2015) Psychological benefits of sports and physical activities. British Journal of Education, Society and Behavioral Science 11: 1-7.

8. Garcia-Falgueras A (2017) Inertial force in sport and fitness with hula hoop as an example. Journal of Education, Society and Behavioral Science 21(3): 1-9.

\section{Your next submission with Juniper Publishers will reach you the below assets}

- Quality Editorial service

- Swift Peer Review

- Reprints availability

- E-prints Service

- Manuscript Podcast for convenient understanding

- Global attainment for your research

- Manuscript accessibility in different formats ( Pdf, E-pub, Full Text, Audio)

- Unceasing customer service

Track the below URL for one-step submission https://juniperpublishers.com/online-submission.php 